\title{
An appreciation of Dr RV Christie
}

\author{
WILLIAM M THURLBECK MD FRCPC
}

On page 21 of this first issue of the Journal we publish the Christie Lecture for 1993. given at Mc Gill University on November 2. 1993. by Dr WM Thurlbeck. Dr Thurlbeck has also provided this brief appreciation of Dr Christie and his career.

Where is the end of them, the fishermen sailing Into the wind's tail, where the fog cowers?

We cannot think of a time that is oceanless

Or of an ocean not littered with wastage

Or of a future that is not liable

Like the past, to have no destination

We have to think of them as forever bailing,

Setting and hauling, while the North East lower

Over shallow banks unchanging and erosionless

Or drawing their money, drying sails at dockage:

Not as making a trip that will be unpayable

For a haul that will not bear examination

$\mathrm{D}$ $r$ David Bates quoted these words from TS Eliot's pocm The Dry Salvages" at at memorial on D) RV Clmistic in 1986.

Ronald Victor Chrssic was born in Edinburgh on Jume 4. 1902 and died in Vancouver on September 27, 1986. His father was a Presbyterian misisonaty who founded the Mukden (now Shenyang) Medical Sichool, and Romald spent the first 11 years of his life in China. He returned to Edinburgh in 1913 to attend George Watson's College in Edinburgh and the Edinburgh Medical School from 1920 to 1925. After a year of internship he spent 1926 to 1928 at the Rockefeller Institute, was then a resident in medicine at the Royal Victoria Hospital, Montreal from 1928 to 1929, and subsequently an assistant in Dr Aschoff's laboratory in Freiburg, Germany from 1929 to 1930. He returned to Montreal as the first full-time research associate of the University Clinic of

Correspondence and reprints: Dr William M Thurlbeck. Depariment of Academic Pathology, GF-227 Koerner Acuse Care Hospital, 2211 Wesbrook Mall, Vancouver. British Columbia V6T 2B5. Telephone (604) 822-7111. Fax (604) 822-7635

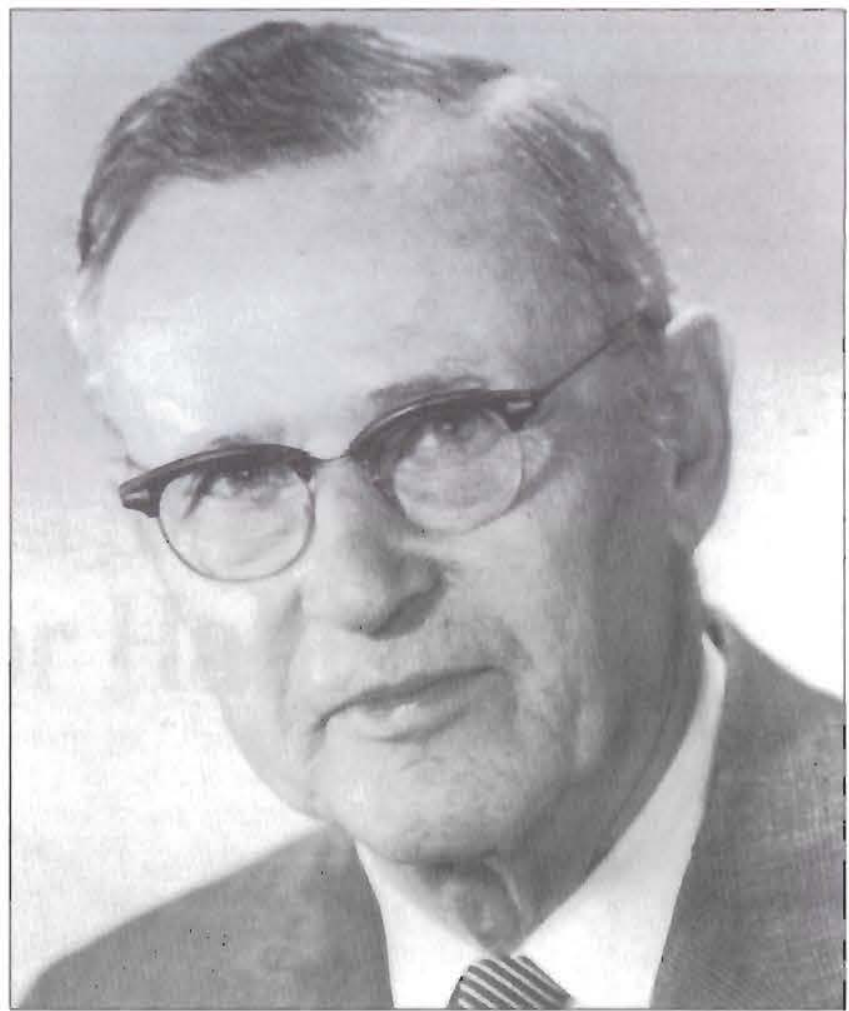

Dr Ronald V Christie

McGill University at the Royal Victoria Hospital. In 1935 he became Reader in Medicine at the London Hospital and in 1938 the first full time Professor of Medicine and Director of Research Laboratories at St Bartholomew's Hospital. In 1955 he came back to McGill to become the Professor and Chairman of the Department of Medicine. He became Dean of the Medical School in 1964 and retired in 1968.

His major contribution during his first sojourn at McGill was in applied lung physiology in the human, and he published original work on the mechanics of breathing and established the loss of recoil of the lungs in emphysema. In Britain he took part in the first clinical trials of penicillin, with 
jarticular interest in bacterial endocarditis. He was an advisor to the British government after the disastrous smog of 1952, which killed some 5000 people. He was responsible for the subsequent legislation that helped to reduce particulate matter in the air. He was offered a knighthood, which he refused. Because he was so young at heart he had a natural affinity for the young, and his major legacy was the number of fellows he influenced in Britain. These included G Hayward (later Dean of the National Heart Hospital), H Morgan (l'rofessor of Medicine at Khartoum), C Phillips (Professor of Physiology, Oxford), KW Donald (Professor of Medicine and Dean at Edinburgh), J Cates (Professor of Medicine and Associate Dean, Bristol), J Knott (Consultant Physician, Portsmouth), MB McIlroy (Professor of Medicine, University of California San Francisco), CB Mckerrow and JE
Cotes of the Pneumonconiosis Research Institute, R Marshall (Reader in Medicine, Oxford), PJ Lawther and R Waller of the Medical Research Council Air Pollution Unit, F Eldridge (Professor of Medicine at University of North Carolina Chapel Hill) and DV Bates (Professor of Medicine, McGill University and later Dean of Medicine, University of British Columbia).

In Montreal, he rejuvenated academic medicine at the Royal Victoria Hospital and through Dr David Bates produced a remarkable cadre of young investigators in respiratory medicine at McGill in the 1960 s. I remember him as a man of great wisdom, totally unpretentious, fiercely honest and a decent, honourable man with a sparkling sense of humour. He believed that the currency of academic medicine was new knowledge. 


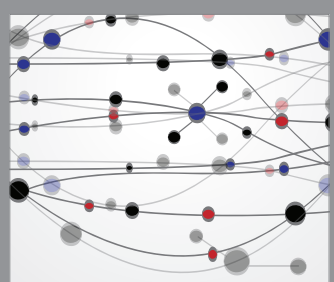

The Scientific World Journal
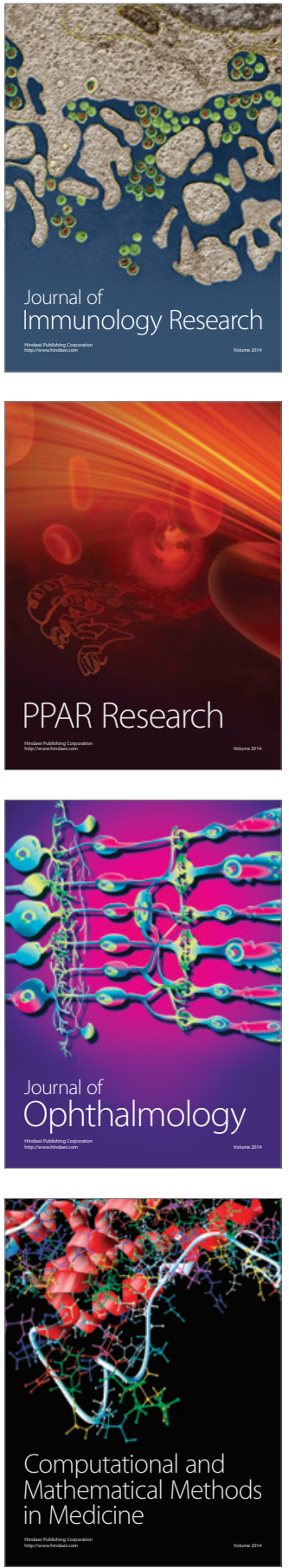

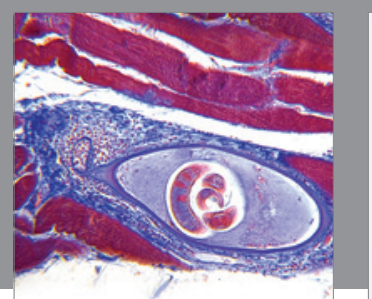

Gastroenterology Research and Practice

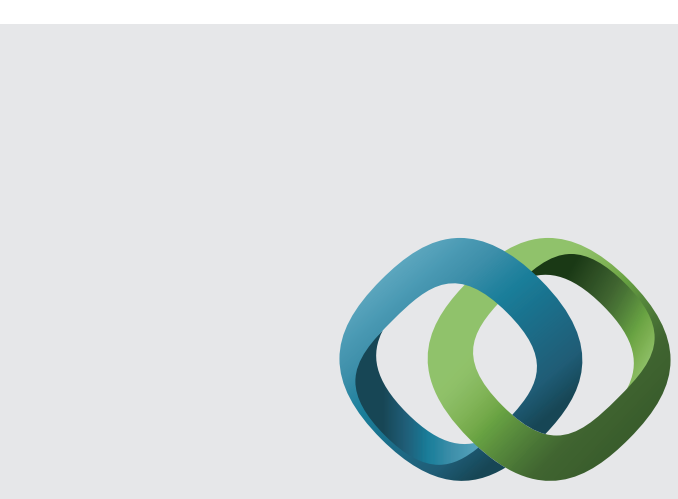

\section{Hindawi}

Submit your manuscripts at

http://www.hindawi.com
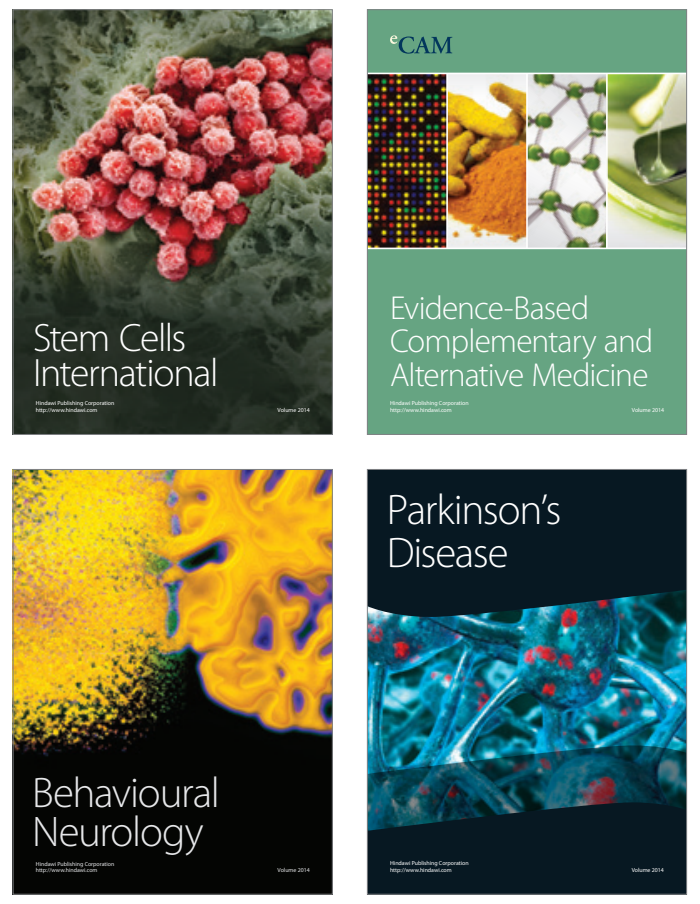
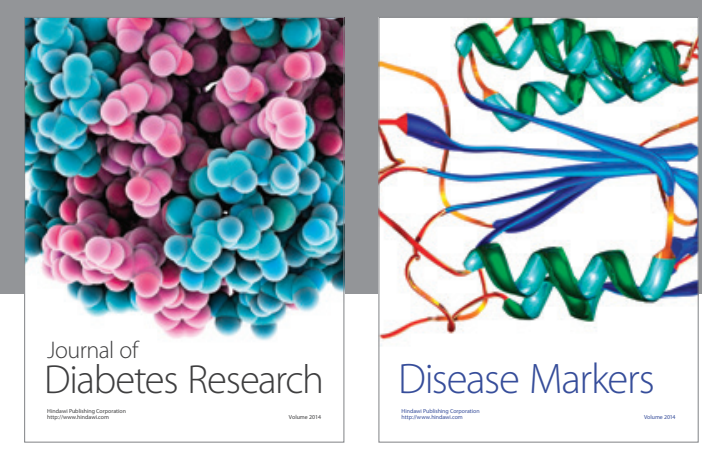

Disease Markers
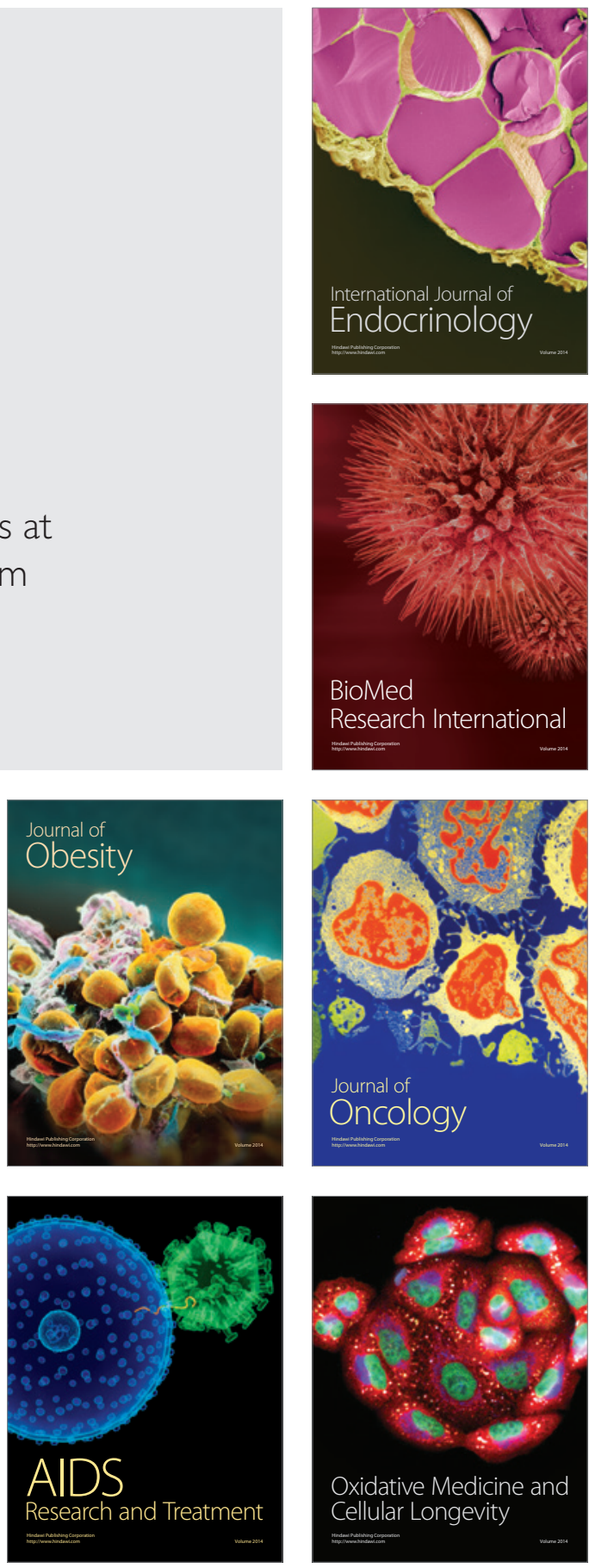